\title{
Immune responses to linear epitopes on the PorB protein of Neisseria meningitidis in patients with systemic meningococcal disease
}

\author{
Alexei A. Delvig, ${ }^{1}$ Elisabeth Wedege, ${ }^{1}$ Terje E. Michaelsen, ${ }^{1}$ \\ E. Arne Høiby, ${ }^{2}$ Petter Brandtzæg ${ }^{3}$ and Einar Rosenquist ${ }^{1}$
}

Author for correspondence: Alexei A. Delvig. 'T'el: +441912226976. Fax: +441912228803.

1,2 National Institute of Public Health, Departments of Vaccinology ${ }^{1}$ and Bacteriology ${ }^{2}, \mathrm{~N}$ 0403 Oslo, Norway

${ }^{3}$ Ullevål University Hospital, Department of Infectious Diseases, N-0407 Oslo, Norway

\begin{abstract}
Neisserial porins, the major protein constituents of the outer membrane capable of inducing antibody responses in humans, are considered to be meningococcal vaccine candidates, so it is important to map the relevant B-cell epitopes. For B-cell epitope analyses of the serotype 15 PorB protein in Neisseria meningitidis, paired sera from selected patients with systemic meningococcal disease (SMD) were screened with synthetic 12mer peptides spanning the PorB protein sequence, and/or its variable region 1 (VR1). A 'SMD-related' linear B-cell epitope was found within the VR1 region consisting of 14 residues ( ${ }^{17}$ svFHQNGQVTEvtt ${ }^{30}$ ). A 23 mer soluble peptide (D63b2) that covered the VR1 region, including the complete ${ }^{17}$ svFHQNGQVTEvtt ${ }^{30}$ sequence, was recognized, whereas no detectable binding was observed to a $16 \mathrm{mer}$ peptide (D63a1) containing most of the essential sequence ( $\left({ }^{19} \mathrm{FHQNGQVTEvtt}{ }^{30}\right)$. A low frequency of IgG responses specific for the PorB linear epitopes was found in convalescent-phase sera from 132 SMD patients studied, as judged from both immunoblotting studies $(24 / 132 ; 18.2 \%)$ and reactivity with peptide D63b2 (18/132; 13.6\%). Peptide D63b2 significantly inhibited IgG binding to the denatured PorB protein on immunoblots, suggesting that this B-cell epitope was one of the main linear epitopes on the PorB protein recognized by sera from some SMD patients.
\end{abstract}

Keywords: Neisseria meningitidis, systemic meningococcal disease, PorB protein, B-cell epitope, synthetic peptides

\section{INTRODUCTION}

Protective immunity against systemic meningococcal disease has been ascribed to antibody-dependent bactericidal killing, and to opsonophagocytic killing by neutrophils (Figueroa \& Densen, 1991; Ross et al., 1987; Griffiss, 1982) and by tissue macrophages mainly involved in the clearance and destruction of bacteria (Benacerraf $e t$ al., 1959). At present, no fully efficient vaccine exists against serogroup $B$ meningococci, at least partly because of the lack of immunogenicity of the group B capsular polysaccharide in humans. Convalescents from meningococcal disease have been reported to mount immune

Present address: Department of Immunology. The Medical School, Framlington Place, University of Newcastle, Newcastle upon Tyne NE2 4HH, UK.

Abbreviations: OMP, outer-membrane protein; OMV, outer-membrane vesicle; SMD, systemic meningococcal disease; VR, variable region. responses against other non-capsular surface antigens (Mandrell \& Zollinger, 1989), which are therefore considred to be meningococcal vaccine candidates (Romero \& Outschoorn, 1994). For example, patients with systemic meningococcal disease (SMD) have been shown to respond to epitopes on the meningococcal PorA protein [class 1 outer-membrane protein (OMP)] (Guttormsen $e t$ al., 1994b; Mandrell \& Zollinger, 1989), suggesting that the Por $A$ protein could be an important component of meningococcal vaccines (Orren et al., 1992; Mandrell \& Zollinger, 1989). In addition, SMD induced significant antibody responses to class 5 OMPs (Poolman et al., 1983; Mandrell \& Zollinger, 1989), Opc protein (Rosenquist et al., 1993; Achtman et al., 1988), Ig A1 protease (Brooks et al., 1992; Morelli et al., 1994), Lip antigen (also designated H.8) (Mæland \& Wedege, 1989; Black et al., 1985), $70 \mathrm{kDa}$ iton-regulated protein (FrpB) (Aoun et al., 1988), transferrin binding protein 2 (Ala'Aldeen et al., 1994), LPS and other outer-membrane components (Mrland \& Wedege, 1989). 
Neisserial porins have attracted significant attention as major protein constituents of the outer membrane (Blake \& Gotschlich, 1986). Studies on the classes 2 and 3 OMPs (also designated PorB proteins) from Neisseria meningitidis identified two alleles of the porB gene (Hitchcock, 1989) sharing sequence homology with other neisserial (Wolff \& Stern, 1991; Ward et al., 1992) and Eschericbia coli (Gotschlich et al., 1987) porins. Molecular modelling of the topology of neisserial porins (van der Ley et al., 1991) predicted that the PorB molecule consisted of eight surface-exposed hydrophilic loops, with loops 1, 5, 6 and 7 bearing four variable regions designated VR1-VR4, respectively (Bash et al., 1995; Feavers et al., 1992; Zapata et al., 1992). Murine PorB-specific $\mathrm{mAbs}$ have been reported to recognize mainly surface-exposed conformational epitopes (Delvig et al., 1995; Zapata et al., 1992), as did PIA-specific mAbs (Mee et al., 1993), and some of them were bactericidal and protective in the infant rat infection model (Saukkonen et al., 1987; Moran et al., 1994). Taken together, the animal studies provided evidence that the PorB protein might also be involved in protection against SMD. Indeed, convalescent-phase sera obtained from patients with SMD showed a high rate of seroconversion to the major OMPs (PorB protein, Por A protein and class 5 OMP) (Poolman et al., 1983; Mandrell \& Zollinger, 1989). Using the purified meningococcal porin proteins, Guttormsen $\varepsilon$ al (1994b, 1993) found that SMD stimulated IgG antibodies specific for both the PorA and PorB proteins in most SMD patients, with the latter antibodies directed to surface-exposed epitopes. Furthermore, affinity-purified antibodies from patients with SMD were found to be bactericidal and opsonic (Guttormsen et al., 1994a), suggesting that the PorB protein might contain potentially protective B-cell epitopes.

Several approaches have been developed to identify epitopes on bacterial and viral antigens, including fragmentation of an antigen by cyanogen bromide treatment (Rothbard et al., 1984), screening large collections of small peptides displayed on filamentous bacteriophage (Meola et al., 1995) and solid-phase synthesis of peptides on polyethylene pins (pepscan method) (Geysen et al., 1984). Using the pepscan method, we have previously observed that the majority of human post-vaccination sera obtained after three doses of the Norwegian meningococcal group B outer-membrane vesicle (OMV) vaccine reacted with a relatively small linear B-cell epitope $\left({ }^{19} \mathrm{FHQNGQVTEVTT}{ }^{30}\right.$ ) located on loop 1 (VR1) of the PorB protein from strain 44/76 (Delvig et al., 1995). 'The aim of the present study was to map B-cell epitopes targeted by immune responses in surviving patients during the course of meningococcal disease.

\section{METHODS}

Patients and serum samples. The first group of SMD patients (group K) included 99 individuals (aged 12-21 years; 52 females and 47 males) infected in Norway during 1988-1991. Of these, 41 patients were participants in the Norwegian group $B$ vaccination trials (Bjune et al., 1991) (14 vaccinees plus 27 placebo controls), and 58 patients were non-participants. Forty-

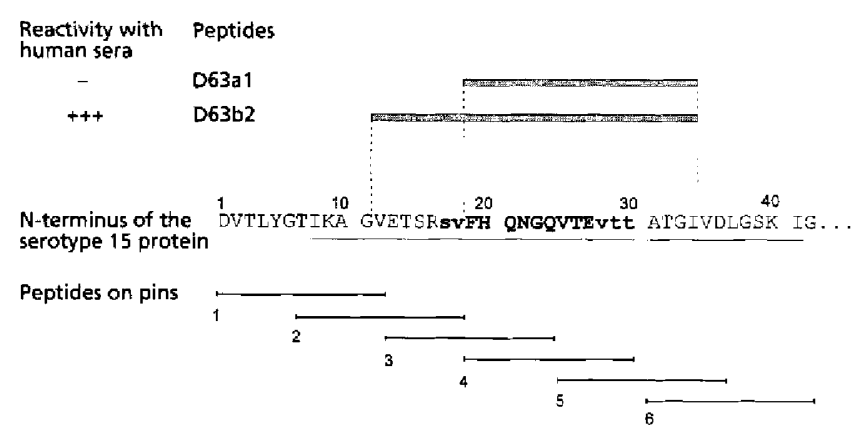

Fig. 1. Synthetic peptides spanning the N-terminal part of the serotype 15 PorB protein. The B-cell epitope recognized by convalescent-phase human sera is shown in boid. Peptides synthesized on pins (12mers overlapping by 6 amino acids) are shown at the bottom, and purified peptides covering the entire loop 1 sequence with the complete B-cell epitope (D63b2), and only part of its structure (D63a1), are shown above. The underlined sequence was covered by all possible 12 mers.

eight group $\mathrm{K}$ patients were infected with serotype 15 meningococci, whilst strains of other serotypes were isolated from the remaining subjects (Høiby et al., 1991). The 14 vaccine-failure patients were immunized at weeks 0 and 6 with $25 \mu \mathrm{g}$ of meningococcal group B OMV vaccine. Late-convalescent sera were collected at least 6 months after the onset of disease, as described by Garred et al. (1993). In addition, paired sera from 30 patients, obrained at admission (acute-phase sera), 1-6 wecks later (convalescent-phase sera) and, for some patients, 1-2 months later, were availabie.

The second group of patients (group U) consisted of 33 individuals (aged $5-50$ years; 20 males and 13 females), who were consecutively admitted to Ullevål University Hospital, Oslo, between 1985 and 1987 (Brandtzxg et al., 1989). Eighteen patients were infected with serotype 15 strains, and the strains isolated from the remaining subjects belonged to other serotypes. Sera were obtained at admission (acute-phase sera), 3-7 weeks later (convalescent-phase sera) and, for some patients, also about 1 year after the SMD episode.

Approval for this study was obtained from the Regional Ethical Committee for Medical Research in Norway. Informed consent was obtained from all the participants or from their parents.

Murine mAbs. 3-1-P15 (setotype 15) and 3-1-P1.16 (serosubtype 16) were provided by Dr W. D. Zollinger, AE3 (class 4) was from Dr C. T. Sacchi and 279-5c (Opc) was produced at the National Institute of Public Health, Norway. All mAbs were available as ascites fluids.

Immunoblotting. All sera from patients were tested on immunoblots against whole-cell preparations (group L) or OMVs (group K) from strain 44/76 as described previously (Wedege ot al., 1988, 1991). After SDS-PAGE and electrotransfer, blots were incubated with human sera (diluted $1: 200$ ) in the absence of Empigen BB (Albright \& Wilson), or murine mAbs in the presence/absence of the detergent to enhance renaturation of the antigens (Wedege et al, 1988). The intensity of IgG binding to the PorB protein was visually scored from 0 to 4 , where scores of $0-1 \cdot 5,2 \cdot 0-2.5$ and $3 \cdot 0-4 \cdot 0$ represented weak, medium and strong binding, respectively.

Solid-phase peptide synthesis. Multiple $\mathrm{N}$-terminally acetylated peptides were synthesized on pins to span the sequence of the setotype 15 PorB protein from strain $44 / 76$ by 12 mers overlapping by 6 amino acids (Fig. 1) using a commercially 
available Epitope Scanning kit V2.0 (Cambridge Research Biochemicals). Other pin-bound peptides covering the VR1 region of the serotype 15 PorB protein by 12 mers with an 11 amino acid overlap were synthesized using Multipin peptide synthesis (non-cleavable block, Chiton Mimotopes Peptide Systems). Peptide synthesis was performed in duplicate.

'The synthetic peptides ${ }^{19} \mathrm{FHQNGQVTEVTTA'TGI}{ }^{34}$ (D63a1, 16mer) and ${ }^{12}$ VETSR SVFHQNGQVTEVTTATGI ${ }^{34}$ (D63b2, 23mer) covering different portions of loop 1 of the serotype 15 PorB protein (Fig. 1) were synthesized as described previously (Delvig et al., 1995). Briefly, synthesis was performed at $0.25 \mathrm{mmol}$ scale using FastMoc technology with an automated peptide synthesizer (model 431 A, Applied Biosystems) on the Rink resin (TentaGel S RAM, Rapp Polymere) providing a Cterminal amide cap. After synthesis, peptides were purified by reversed phase HPLC (Pep-S, C2/C18, $100 \AA$ pore size, $22.5 \mathrm{~mm} \times 25 \mathrm{~cm}$, Pharmacia) using a $0-40 \%$ gradient of acetonitrile $/ 0 \cdot 1 \%$ trifluoroacetic acid. Lyophilized peptides were stored at $-20^{\circ} \mathrm{C}$.

Epitope mapping. After incubation with blocking buffer [0.01 M PBS (0.01 M sodium phosphate buffer $\mathrm{pH} \mathrm{7.2,} \mathrm{con-}$ taining $0 \cdot 15 \mathrm{M} \mathrm{NaCl}), 2 \%(\mathrm{w} / \mathrm{v}) \mathrm{BSA}, 0 \cdot 1 \%$ Tween $20,0.05 \%$ $\mathrm{NaN}_{3}$ ) for $90 \mathrm{~min}$ at room temperature, the pin-bound synthetic peptides were screened in ELISA with sera (diluted 1:500 in blocking buffer) obtained from SMD patients. After incubation for $18 \mathrm{~h}$ at $4^{\circ} \mathrm{C}$, the pins were reacted with horseradishperoxidase-conjugated rabbit anti-human Ig ( $\gamma$-chains) (1:500) (Dakopatts) for $90 \mathrm{~min}$, and the reactions were read at $A_{405}$. Each serum sample was tested on two occasions against two separate pin sets.

Synthetic peptide ELISA. Peptide D63b2 (5 $\left.\mu \mathrm{g} \mathrm{m}^{-1}\right)$ was coated on MaxiSorp Nunc-Immuno plate F96 (Nunc) in $0.05 \mathrm{M}$ carbonate buffer, $\mathrm{pH} 9.6$ for $16 \mathrm{~h}$ at $35^{\circ} \mathrm{C}$. The plates were then blocked with PBS containing $2 \%$ BSA and $0.05 \%$ Tween 20 for $90 \mathrm{~min}$ at room temperature. Tests with human sera (diluted $1: 50$ ) were performed in triplicate. The reaction was developed with alkaline phosphatase conjugate (diluted 1:500) of swine anti-human $\operatorname{IgG}(\gamma$-chain specific) (Orion Diagnostica). Values showing more than threefold increases in $A_{405}$ above the mean background level were considered significant.

Inhibition experiments. Increasing, 10-foid amounts of peptide D63b2 (from 0.004 to $4 \mathrm{nmol}$ ) were added to sera from selected patients and incubated for $16 \mathrm{~h}$ at $4{ }^{\circ} \mathrm{C}$. Inhibition by the soluble peptide was observed on immunoblots as a decrease in the intensity of the immunoreactive PorB protein band.

Statistics. Statistical analyses were performed using CSS: Statistica for Windows (Statsoft) and/or Statgraphics 3.01 (STSC) and an IBM-compatible PC.

\section{RESULTS}

\section{PorB- and peptide D63b2-specific IgG responses in SMD patients}

Convalescent-phase sera from 99 group $\mathrm{K}$ patients and from 33 group $U$ patients were screened for reactivity against linear epitopes on the denatured PorB protein on immunoblots and to peptide D63b2 in ELISA. Lateconvalescent sera from $21 / 99(21 \cdot 2 \%)$ of group $K$ patients bound to the PorB protein on immunoblots with medium/high intensity, of which $15 / 21(71.4 \%)$ patients developed significant IgG responses to peptide D63b2 (7 vaccinees and 8 non-vaccinees). Of the 15 responders, 10 were infected with the serotype 15 strains, one with serotype 4 , and the remaining four patients were culturenegative cases with clinically confirmed diagnosis of SMD (Høiby et al., 1991). Except in three cases, convalescentphase sera from the unvaccinated group $\mathrm{U}$ patients reacted with neither the PorB protein nor peptide D63b2. Sera from the three exceptional subjects (serotype 15 strains; two patients with septicacmia, and one with meningococcaemia), obtained 3-6 weeks or 1 year after the disease, reacted weakly both with the denatured serotype 15 PorB protein on immunoblots and with peptide D63b2 in peptide ELISA (data not shown).

Altogether, a low frequency of $\operatorname{IgG}$ specific for the linear epitopes was found in sera from all 132 SMD patients studied: 24/132 patients responded to the denatured PorB protein on immunoblots (mean $18.2 \%$; 95\% confidence interval $12 \cdot 0-25 \cdot 8 \%$ ), and $18 / 132$ patients (mean 13.6\%; 95\% confidence interval $8 \cdot 3-20.7 \%$ ) responded to peptide D63b2 in ELISA.

\section{Mapping of linear B-cell epitopes on the serotype 15 PorB protein}

Epitope mapping experiments were performed with paired sera from four SMD patients (two patients with meningitis - K-131 and K-199, and two pateints with meningococcal septicaemia-K-15 and U-17) infected with virulent ET-5 complex strains ( $B: 15: P 1.7,16)$, plus one patient $(\mathrm{K}-54)$ infected with B:15:P1.12,13a strain. The current selection was based on the pronounced reactivity of the sera with the denatured PorB protein on immunoblots (data not shown), suggesting the presence of detectable levels of antibodies reactive with linear epitopes. In addition, the protocol used allowed the study of epitopes recognized under different clinical forms of SMD.

Convalescent sera, unlike the acute-phase sera, obtained from both patients with meningitis (K-131 from the vaccinees group, and K-199 from the placebo control group) mainly reacted with a single peptide $\left({ }^{19} \mathrm{FHQNGQVTEVTT}{ }^{30}\right.$, peptide no. 4) (Fig. 2b, c), whilst no increased reactivity to other peptides was found. Infection induced a strong response against this $12 \mathrm{mer}$ peptide in the vaccinated patient K-131 $14 \mathrm{~d}$ after admission but no such reactivity was detected in the paired late-convalescent serum obtained 19 months later (data not shown). In the unvaccinated patient K-199, peptide 4 reactivity was detected in the late-convalescent serum obtained 9 months after the SMD episode, but not in the acute-phase serum taken $9 \mathrm{~d}$ after admission (data not shown).

Early convalescent-phase sera (15-21 d) from two patients with meningococcal septicaemia (K-15 and $\mathrm{U}-17)$ showed two- to fivefold increases in reactivity against the majority of peptides (Fig. 2d, e). A significant response against peptide ${ }^{19} \mathrm{FHQNGQVTEVTT}{ }^{30}$ was detected only in the serum from the previously vaccinated patient $\mathrm{K}-15$. This pattern of polyclonal reactivity is likely to reflect the immunomodulating activity of meningococcal LPS 

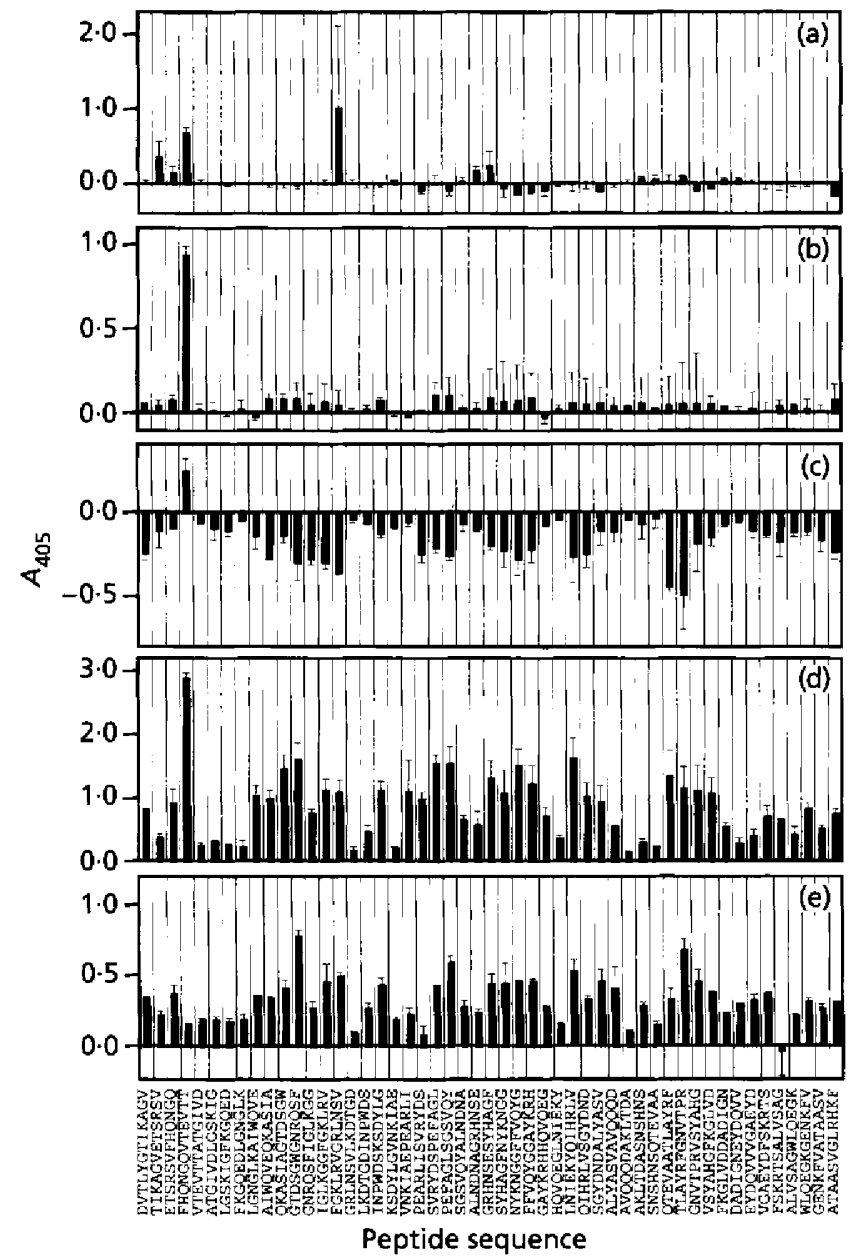

Fig. 2. ELISA reactivity of paired sera from five patients with systemic meningococcal disease with synthetic $12 \mathrm{mer}$ peptides on pins spanning the PorB molecule. Data are presented as difference in reactivities between immune serum versus preimmune serum obtained at admission. (a) Late-convalescent serum from unvaccinated patient K-54, 26 months after disease; (b) acute-phase serum from vaccinated patient K-131 with meningitis, $14 \mathrm{~d}$ after admission; (c) late-convalescent serum from the unvaccinated patient $\mathrm{K}-199$ with meningitis, 9 months after disease; (d) acute-phase serum from vaccinated patient K-15 with septicaemia, $15 \mathrm{~d}$ after admission; (e) acute-phase serum from unvaccinated patient $\mathrm{U}-17$ with septicaemia, $21 \mathrm{~d}$ after admission. Results are the means of two separate experiments obtained on two different sets of pins. The filled bars represent the means, and the error bars show SEM.

(Melancon Kaplan \& Murgita, 1987) and/or elevated antigenic load in septic patients (Brandtzæg et al., 1989).

Late-convalescent serum (26 months) from another unvaccinated patient (K-54) bound to peptide no. 15 $\left({ }^{85}\right.$ FGKLRVGRLNSV $\left.{ }^{96}\right)$, in addition to peptide no. 4 , implying the presence of other linear B-cell epitopes on the PorB protein (Fig. 2a). According to the topology model for neisserial porins (van der Ley et al., 1991), this additional B-cell epitope was located on the transmembrane amphipathic $\beta$-strand between loops 2 and 3 plus a short loop on the periplasmic face, and probably was not exposed on the cell surface. To study other
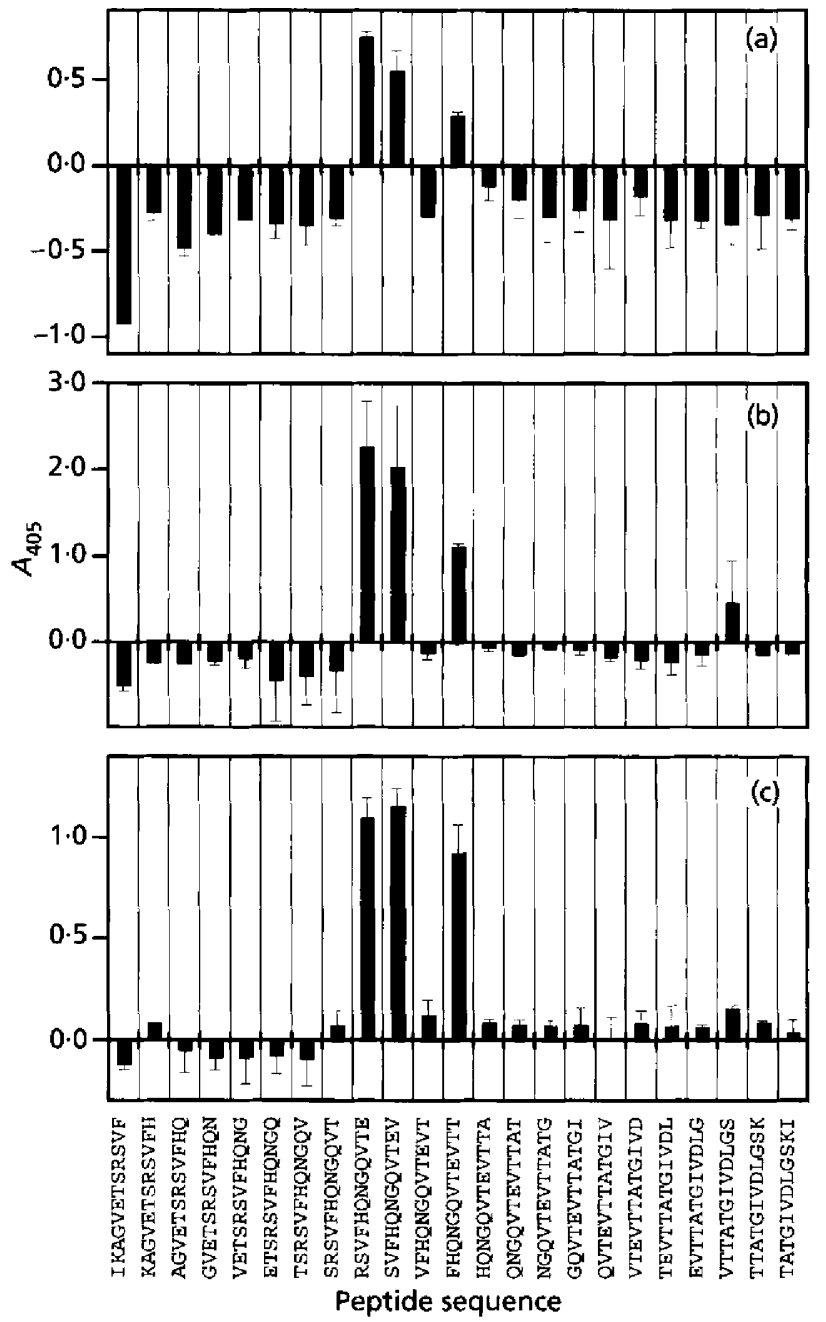

Fig. 3. ELISA reactivity of paired sera from three SMD patients with synthetic $12 \mathrm{mer}$ peptides on pins spanning the VR1 region. Data are presented as the difference in reactivities between immune serum versus pre-immune serum obtained at admission from patient K-199 (a), patient K-131 (b) and patient K-54 (c). Other details as in legend to Fig. 2.

putative B-cell epitopes in more detail, late-convalescent sera from an additional six group $\mathrm{K}$ patients, which reacted with medium intensity with the denatured Por $B$ protein on immunoblots, were subjected to epitope mapping, but no significant responses with single peptides were detected (data not shown).

\section{Further definition of the B-cell epitope within the VR1 region}

To define the linear structure of this B-cell epitope in more detail, $12 \mathrm{mer}$ peptides, having 11 amino acids in common, were synthesized on pins to span the VR1 region. Paired sera from only three of the abovementioned patients (K-199, K-131 and K-54) were tested. All three showed a similar pattern of reactivity (Fig. 3a-c, respectively). These data suggested that the B-cell epitope 


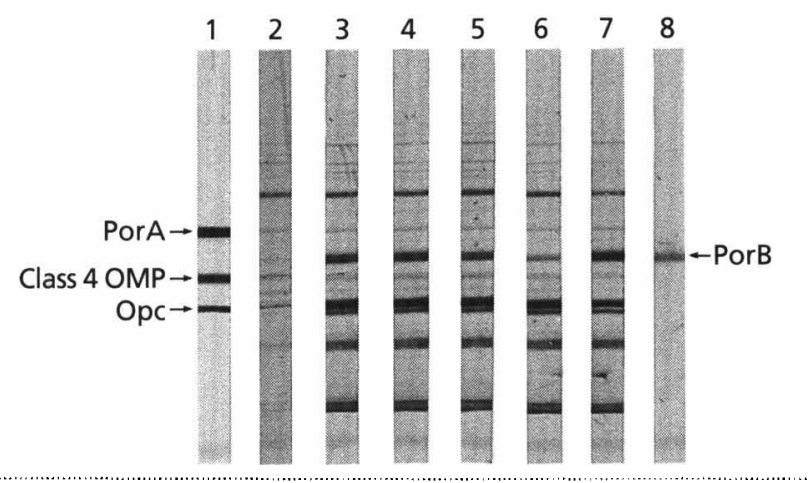

Fig. 4. Reactivity of paired sera from an unvaccinated patient (K-54) with systemic meningococcal disease against OMVs from strain $44 / 76$ on immunoblots in the absence of detergent. Tracks: 1 , strip developed with murine mAbs specific for PorA, class 4 OMP and Opc protein; 2, acute-phase serum; 3-7, serum taken 26 months later containing $0.004,0.04,0.4,4 \mathrm{nmol}$ or no peptide D63b2, respectively (inhibition experiment); 8, strip with murine serotype-15-specific $m A b$ incubated in the presence of $0.25 \%$ Empigen BB.

within the $V R 1$ region consisted of the minimal sequence ${ }^{19}$ FHQNGQVTF ${ }^{27}$ plus ${ }^{17} \mathrm{sv}^{18}$ and/or ${ }^{28} \mathrm{vtt}^{30}$ residues probably being essential for binding. To test this hypothesis, purified synthetic peptides corresponding to different portions of the loop 1 (VR1) region were screened with convalescent-phase sera, and essentially no reactivity was detected with peptide D63a1 that covered only part of the epitope $\left({ }^{19} \mathrm{FHQNGQVTFvtt}{ }^{30}\right.$ ) (data not shown). In contrast, peptide D63b2 containing the complete B-cell epitope was efficiently recognized by these sera; thus the complete epitope comprises the 14 amino acids ${ }^{17}$ svFHQNGQVTFvtt ${ }^{30}$ (Fig. 1). Interestingly, the pin bearing peptide no. 4 with the ${ }^{19}$ FHQNGQV'TEvtt ${ }^{30}$ sequence was strongly reactive with human scra. This apparent discrepancy between pinbound and free peptides might reflect some limitations of the pepscan method since high peptide concentrations on the solid-phase can facilitate bivalent reactions and crossreactivity (Van Regenmortel, 1992).

\section{Inhibition efficiency of peptide D63b2}

To test if the 'SMD-related' B-cell-epitope-specific IgG response was immunodomitiant, peptide $\mathrm{D} 63 \mathrm{~b} 2$ was added to scra from patients $\mathrm{K}-199, \mathrm{~K}-131$ and $\mathrm{K}-54$, and data on patient K-54 is shown in Fig. 4. The presence of increasing amounts of peptide D63b2 (0.004-4 nmol) resulted in a gradual partial reduction in $\operatorname{IgG}$ binding to the denatured PorB protein on immunoblots, whereas reactivities against other OMPs remained intact (Fig. 4, tracks 3-6). Absorbtion of the sera with epidemic strain $44 / 76$ resulted in complete inhibition of binding to the PorB protein (data not shown). These data are in agreement with observations by Guttormsen et al. (1993) that the PorB-specific antibodies in SMD patients are mainly directed to surface-exposed epitopes.

\section{DISCUSSION}

Recent studies have shed light on the target antigens recognized by the immune system during infection by pathogenic Neisseria species. In this respect, neisserial porins are receiving increasing attention as abundant components of the outer membrane (Blake \& Gotschlich, 1986) capable of activating T-lymphocytes through the HLA class II-restricted pathway (Wiertz et al., 1991 , 1992), as well as stimulating B-lymphocyte proliferation and differentiation into antibody-secreting cells (Guttormsen et al., 1993, 1994b; Wetzler et al., 1988). In addition, neisserial porins appear to be potent immunomodulators, and are therefore used as protein carriers in different experimental vaccines (Lowell et al., 1988; Livingston et al., 1993; Siber, 1994).

Here, we demonstrate that some SMD patients develop $\mathrm{IgG}$ antibody responses to peptide $\mathrm{D} 63 \mathrm{~b} 2$ bearing a linear B-cell epitope $\left({ }^{17} \mathrm{svFHQNGQV}\right.$ TEvtt $\left.{ }^{30}\right)$ mapped to the N-terminus (VR1) of the serotype 15 PorB protein. This antigenic PorB variant has been shown to be expressed by ET-5 complex strains which have caused epidemics of meningococcal disease in Norway and other countries since the mid-1970s (Caugant et al., 1989). The N-terminal parts of the PIA and the PIB porins in N. gonorrboeae have also been reported to be immunogenic and capable of inducing bactericidal antibodies (Elkins et al., 1992). As mentioned above, only a small proportion of 132 SMD patients studied here responded to the denatured PorB protein on immunoblots $(24 / 132 ; 18.2 \%)$ or with peptide D63b2 $(18 / 132 ; 13.6 \%)$, and these responders were infected mainly with serotype 15 meningococcal strains. By contrast, $74 \%$ of post-vaccination sera obtained from vaccinees after three doses of the Norwegian group $B$ OMV vaccine bound to the denatured Por $B$ protein and peptide D63b2 (Delvig et al., 1995), suggesting that, unlike SMD, vaccination gave rise to a higher frequency of antibodies directed to the linear B-cell epitopes. The apparent differences between human responses to the linear B-cell epitope observed after vaccination and SMD could have resulted from the immunization protocol involving several administrations of the OMV vaccine during the Norwegian vaccination trial (Bjune et al., 1991), or could have reflected more efficient mechanisms of antigen processing and presentation for the OMV vaccine compared to that for bacteria. On the other hand, SMD has been shown to give rise to high levels of PorBspecific antibodies (up to $100 \mu \mathrm{g} \mathrm{ml}^{-1}$ and greater) in scra from most SMD patients, as reported in quantitative kinetic studies with the purified PorB protein by Guttormsen et al. (1993); these antibodies were probably targeted to conformational epitopes and were not detected in the present study.

Under the experimental conditions used, SMD was found to induce anamnestic $\operatorname{IgG}$ responses against peptide D63b2 in early convalescent-phase sera from $7 / 14$ group $\mathrm{K}$ patients, previously immunized with the Norwegian OMV vaccine, whereas only late-convalescent sera from unvaccinated group $\mathrm{K}$ patients contained detectable levels 
of peptide-specific IgG antibodies. The delayed appearance of the D63b2-specific antibodies in the latter sera described here is in agreement with earlier observations that the PorB-specific IgG can only be detected in lateconvalescent phase sera from patients on immunoblots (Wedege et al., 1991). This phenomenon may to some extent be attributed to the carriage of serotype 15 strains, which is of relatively low rate in the Norwegian population (Caugant $e t$ al., 1994). Alternatively, the delayed D63b2-specific responses could have originated from the impaired T-helper-cell function for B-lymphocytes described in patients with bacterial meningitis, namely upregulation of both $\gamma / \delta$-T-cells and $\alpha / \beta$-T-cells with suppressor-inducer phenotype $\left(\mathrm{CD}^{+} \mathrm{CD} 45 \mathrm{R}^{+}\right)$, and reciprocal down-regulation of helper-inducer-T-cells $\left(\mathrm{CD} 4{ }^{+} \mathrm{CDw} 29^{+}\right.$) (Raziuddin et al., 1991, 1994). Interestingly, the loop 1 region in the serotype 15 PorB protein covered by peptide D63b2 shares 16 out of 23 amino acids (69.6\% homology) with its serotype 4 counterpart (Lapata et al., 1992; Ward et al., 1992). This homology may explain the observed cross-reactivity for peptide D63b2 of a convalescent-phase scrum from the patient infected with a serotype 4 strain (data not shown), although we cannot rule out that this patient became a carrier of a serotype 15 strain.

To be effective, a peptide-based vaccine has to contain different appropriate epitopes in order to overcome the variation in immune responses resulting from histocompatibility leucocyte antigen (HLA) heterogeneity, and to induce $\mathrm{T}$ - and $\mathrm{B}$-cell activation and differentiation (Ada, 1992). The HLA heterogeneity could therefore account for the relatively low frequency of the peptideD63b2-specific responses in SMD patients infected with serotype 15 strains that was observed here. Although an HLA-DR1 binding motif has been shown to overlap with the B-cell epitope (Delvig $e t$ al., 1995), there was no significant association between expression of a particular HLA-DR haplotype in $\mathrm{K}$ patients and antibody responses to peptide D63b2 (unpublished data).

So far, information about human B- and T-cell epitopes on meningococcal antigens is limited to capsular polysaccharide (Kabat et al., 1988), and some non-capsular antigens (Wiertz et al., 1992; Delvig et al., 1994; de Cossio et al., 1992; Morelli et al., 1994). In this context, the B-cell epitope described in this report will add to the limited collection of epitopes recognized by human immune sera.

\section{ACKNOWLEDGEMENTS}

We are grateful to Dr M. Achtman for stimulating discussions and for help in synthesizing peptides. We thank Dr J. H. Robinson for support and for critically reading the manuscript. We thank Dr F. Vartdal for the HLA-typing of the SMD K patients. We also wish to thank Dr R. Dalseg and Dr F. Oftung for discussions, and $K$. Bolstad for excellent technical assistance. We are also grateful to Drs W. D. Zollinger, C. T. Sacchi and J. Kolberg for providing murine mAbs. This research project received financial support from the WHO Global Programme for Vaccines (GPV): GPV/V23/181/52.

\section{REFERENCES}

Achtman, M., Neibert, M., Crowe, B. A., Strittmatter, W., Kusecek, B., Weyse, E., Walsh, M. J., Slawig, B., Morelli, G., Moll, A. \& Blake, M. (1988). Purification and characterization of eight class 5 outer membrane protein variants from a clone of Neisseria meningitidis serogroup A. J Exp Med 168, 507-525.

Ada, G. L. (1992). Vaccinc antigens. In Strutture of Antigens, pp. 367-391. Edited by M. H. V. Van Regenmortel. London: CRC Press.

Ala'Aldeen, D. A. A., Stevenson, P., Griffiths, E., Gorringe, A. R., Irons, L. I., Robinson, A., Hyde, S. \& Borriello, S. P. (1994). Immune responses in humans and animals to meningococcal transferrinbinding proteins: implications for vaccine design. Infert Immun 62 , 2984-2990

Aoun, L., Lavitola, A., Aubert, G., Prère, M. F., Cremieux, A. C. \& Martin, P. M. V. (1988). Human antibody response to the $70-\mathrm{kDa}$ common neisserial antigen in patients and carriers of meningococci or non-pathogenic Neisseria. Ann Inst Pasteur Immunol 139, 203-212.

Bash, M. C., Lesiak, K. B., Banks, S. D. \& Frasch, C. E. (1995). Analysis of Neisseria meningitidis class 3 outer membrane protein gene variable regions and type identification using generic techniques. Infect Immun 63, $1484-1490$.

Benacerraf, B., Sebestyen, M. M. \& Schlossman, S. (1959). A quantitative study of the kinetics of blood clcarance of $\mathrm{P}^{32}$-labelled Eschericbia cali and staphylococci by the reticuloendothelial system. $J$ Exp Med 110, 27-48.

Bjune, G., Høiby, E. A., Grønnesby, J. K., Arnesen, O., Fredriksen, J. H., Halstensen, A., Holten, E., Lindbak, A.-K., Nøkleby, H., Rosenqvist, E., Solberg, L. K., Closs, O., Eng, J., Frøholm, L. O., Lystad, A., Bakketeig, L. S. \& Hareide, B. (1991). Effect of outer membrane vesicle vaccine against group $B$ meningococcal disease in Norway. Lancet 338, 1093-1096.

Black, J. R., Black, W. J. \& Cannon, J. G. (1985). Neisserial antigen $H .8$ is immunogenic in patients with disseminated gonococcal and meningococcal infections. I Infect Dis 151, 650-657.

Blake, M. S. \& Gotschlich, E. C. (1986). Functional and immunological properties of parhogenic neisserial surface proteins. In Bacterial Outer Mombraner as Model Systems, pp. 377-400. Edited by M. Inouye. New York: John Wiley.

Brandtzæeg, P., Kierulf, P., Gaustad, P., Skulberg, A., Bruun, J. N., Halvorsen, S. \& Sorensen, E. (1989). llasma endotoxin as predictor of multiple organ failure and death in systemic meningococcal disease. I Infect Dis 159, 195-204.

Brooks, G. F, Lammel, C. J., Blake, M. S., Kusecek, B. \& Achtman, M. (1992). Antibodies against $\operatorname{Ig} A 1$ protease are stimulated both by clinical disease and by asymptomatic carriage of serogroup $A$ Neisseria mertingitidis. I Infect Dis 166, 1316-1321.

Caugant, D. A., Frøholm, L. O., Selander, R. K. \& Bøvre, K. (1989). Sulfonamide resistance in Neisseria meningitidis isolates of clones of the ET-5 complex. APMIS 97, 425-428.

Caugant, D. A., Høiby, E. A., Magnus, P., Scheel, O., Hoel, T., Bjune, G., Wedege, E., Eng, J. \& Froholm, L. O. (1994). Asymptomatic carriage of Neisseria meningitidis in a randomly sampled population. I Clin Microbiol 32, 323-330.

de Cossio, M. E. F., Ohlin, M., Llano, M., Selander, B., Cruz, S., del Valle, J. \& Borrebaeck, C. A. K. (1992). Human monoclonal antibodies against an epitope on the class $5 \mathrm{c}$ outer membranc. protein common to many pathogenic strains of Neisseria meningitidis. J Infect Dis 166, 13221328.

Delvig, A., Jahn, S., Kusecek, B., Heckels, J. E., Rosenqvist, E., Høiby, E. A.، Michaelsen, T. E. \& Achtman, M. (1994). A com- 
parison of human and murine monoclonal IgGs specific for the $\mathrm{P} 1.7$ PorA protein of Neisseria meningitidis. Mol Immunol 31, 1257-1267.

Delvig, A. A., Wedege, E., Caugant, D. A., Dalseg, R., Kolberg, J., Achtman, M. \& Rosenqvist, E. (1995). A linear B-cell epitope on the class 3 outer-membrane protein of Neisseria meningitidis recognized after vaccination with the Norwegian group B outer-membrane vesicle vaccine. Microbiology 141, 1593-1600.

Elkins, C., Carbonetti, N. H., Varela, V. A., Stirewalt, D., Klapper, D. G. \& Sparling, P. F. (1992). Antibodies to $N$-terminal peptides of gonococcal porin are bactericidal when gonococcal lipopolysaccharide is not sialylated. Mol Microbiol 6, 2617-2628.

Feavers, I. M., Suker, J., McKenna, A. J., Heath, A. B. \& Maiden, M. C. J. (1992). Molecular analysis of the serotyping antigens of Neisseria meningitidis. Infect Immun 60, 3620-3629.

Figueroa, J. E. \& Densen, P. (1991). Infectious diseases associated with complement deficiencies. Clin Microbiol Kev 4, 359-395.

Garred، P., Michaelsen, T. E., Bjune, G., Thiel, S. \& Svejgaard, A. (1993). A low serum concentration of mannan-binding protein is not associated with serogroup $B$ or $C$ meningococcal disease. Scand J Immunol 37, 468-470.

Geysen, H. M., Meloen, R. H. \& Barteling, S. J. (1984). Use of peptide synthesis to probe viral antigens for epitopes to a resolution of a single amino acid. Proi Natl Acad Soi USA 81, 3998-4002.

Gotschlich, E. C., Seiff, M. E., Blake, M. S. \& Koomey. M. (1987). Porin protein of Neisseria gonorrboeae: cloning and gene structure. Proc Natl Acad Soi US.A 84, 8135-8139.

Griffiss, J. M. (1982). Epidemic meningococcal disease : synthesis of a hypothetical immunoepidemiologic model. Rev Infert Dis $\mathbf{4}$, $159-172$.

Guttormsen, H.-K., Wetzler, L. M. \& Næss, A. (1993). Humoral immune response to the class 3 outer membrane protein during the course of meningococcal disease. Infect Immun 61, 4734-4742.

Guttormsen, H.-K., Wetzler, L. M. \& Solberg, C. O. (1994a). Serum opsonins induced during the course of meningococcal disease correlate with anti-outer membrane protein antibodies. In Proceedings of the Ninth Pathogenic Neisseria Conference, pp. 54-55. Edited by J.S. Evans, S. E. Yost, M. C. J. Maiden \& I. M. Feavers. Winchester, UK.

Guttormsen, H.-K., Wetzler, L. M. \& Solberg, C. O. (1994b). Humoral immune response to class 1 outer membrane protein during the course of meningococcal disease. Infect Immun 62, 1437-1443.

Hitchcock, P. J. (1989). Unified nomenclature for pathogenic Neisseria species. Clin Microbiol Rev (Supplement) 2, S64-S65.

Høiby, E. A., Bjune, G., Froholm, L. O., Eng, J., Halstensen, A.r Rosenqvist, E., Rønnild, E. \& Wedege, E. (1991). The Norwegian meningococcal serogroup $B$ outer membrane vesicle protection trials : case tracing, meningococcal antigen detection and serological diagnosis. NIPH $A n n$ 14, 107-123.

Kabat, E. A., Liao, J., Osserman, E. F., Gamian, A., Michon, F. \& Jennings, H. J. (1988). The epitope associated with the binding of the capsular polysaccharide of the group B meningococcus and of Eschericbia coli $\mathrm{K} 1$ to a human monoclonal macroglobulin, IgMNOV. J Exp Med 168, 699-711.

van der Ley, P., Heckels, J. E., Virji, M., Hoogerhout, P. \& Poolman, J. T. (1991). Topology of outer membrane porins in pathogenic Neisseria spp. Infect Immun 59, $2963-2971$.

Livingston, P. O., Calves, M. J., Helling, F., Zollinger, W. D., Blake, M. S. \& Lowell, G. H. (1993). GD3/proteosome vaccines induce consistent IgM antibodies against the ganglioside GD3. Vaccine 11, 1199- 1204.
Lowell, G. H., Ballou, W. R., Smith, L. F., Wirtz, R. A. \& Zollinger, W. D. (1988). Proteosome-lipopeptide vaccines: enhancement of immunogenicity for malaria CS peptides. Science 240, 800-802.

Mæland, J. A. \& Wedege, E. (1989). Serum antibodies to crossreactive Neisseria outer membrane antigens in healthy persons and patients with meningococcal disease. APMIS 97, 774. 780.

Mandrell, R. E. \& Zollinger, W. D. (1989). Human immune response to meningococcal outer membrane protein epitopes after natural infection or vaccination. Infect Immun 57, 1590-1598.

Mee, B. J., Thomas, H., Cooke, S. J., Lambden, P. R. \& Heckels, J. E. (1993). Structural comparison and epitope analysis of outermembrane protein PIA from strains of Neisseria gonorrboed with different serovar specificities. J Gen Microbiol 139, 2613-2620.

Melancon Kaplan, J. \& Murgita, R. A. (1987). Modulation of the immune system by Neisseria meningitidis. Siand J Immunol 26, 213-221.

Meola, A., Delmastro, P., Monaci, P., Luzzago, A., Nicosia, A., Felici, F., Cortese, R. \& Galfre, G. (1995). Derivation of vaccines from mimotopes. Immunologic properties of human Hepatitis B virus surface antigen mimotopes displayed on filamentous phage. J Immunol 154, 3162-3172.

Moran, E. E., Brandt, B. L. \& Zollinger, W. D. (1994). Expression of the L8 lipopolysaccharide determinant increases the sensitivity of Neisseria meningitidis to serum bactericidal activity. Infect Immun 62, 5290-5295.

Morelli, G., del Valle, J., Lammel, C. J., Pohiner, J., Muller, K., Blake, M., Brooks, G. F., Meyer, T. F., Koumaré, B., Brieske, N. \& Achtman, M. (1994). Immunogenicity and evolutionary variability of epitopes within IgA1 protease from serogroup $\Lambda$ Neisseria meningitidis. Mol Microbiol 11, 175187.

Orren, A., Warren, R. E., Potter, P. C., Jones, A. M., Lachmann, P. J. \& Poolman, J. T. (1992). Antibodies to meningococcal class 1 outer membrane proteins in South African complement-deficient and complement-sufficient subjects. Infect Immun 60, 4510-4516.

Poolman, J. T., Hopman, C. T. P. \& Zanen, H. C. (1983). Immunogenicity of meningococcal antigens as detected in patient sera. Infect Immun 40, 398-406.

Raziuddin, S., El-Awad, M. E. \& Mir, N. A. (1991). Bacterial meningitis: $\mathrm{T}$ cell activation and immunoregulatory $\mathrm{CD} 4^{+} \mathrm{T}$ cell subset alteration. J Allergy Clin Immunol 87, 1115-1120.

Raziuddin, S., Mir, N. A., El-Awad, M. E., Telmesani, A. W. \& AlJanadi, M. (1994). $\gamma / \&$-T lymphocytes and proinflamatory cytokines in bacterial meningitis. J Allergy Clin Immunol 93, 793-789.

Romero, J. D. \& Outschoorn, I. M. (1994). Current status of meningococcal group $B$ vaccine candidates: capsular or noncapsular? Clin Microbiol Rev 7, 559-575.

Rosenqvist, E., Høiby, E. A., Wedege, E., Kusecek, B. \& Achtman, M. (1993). The $5 \mathrm{C}$ protein of Neisseria meningitidis is highly immunogenic in humans and stimulates bactericidal antibodies. $J$ Infect Dis 167, 1065-1073.

Ross, S. C., Rosenthal, P. J., Berberich, H. M. \& Densen, P. (1987). Killing of Neisseria meningitidis by human neutrophils : implications for normal and complement-deficient individuals. I Infect Dis $\mathbf{1 5 5}$, $1266-1275$.

Rothbard, J. B., Fernandez, R. \& Schoolnik, G. K. (1984). Strainspecific and common epitopes of gonococcal pili. J Exp Med 160 , 208221.

Saukkonen, K., Abdillahi, H., Poolman, J. T. \& Leinonen, M. (1987). Protective efficacy of monoclonal antibodies to class 1 and class 3 outer membrane proteins of Neisseria meningitidis B: $15:$ P1.16 
in infant rat infection model: new prospects for vaccine development. Microb Pathog 3, 261-267.

Siber, G. R. (1994). Pneumococcal disease: prospects for a new generation of vaccines. Science 265, 1385-1387.

Van Regenmortel, M. H. V. (1992). Molecular dissection of protein antigens. In Structure of Antigens, vol. 1, pp. 1-27. Edited by M. H. V. Van Regenmortel. London: CRC Press.

Ward, M. J., Lambden, P. R. \& Heckels, J. E. (1992). Sequence analysis and relationships between meningococcal class 3 serotype proteins and other porins from pathogenic and non-pathogenic Neisseria species. FEMS Microbiol Lett 73, 283-289.

Wedege, E., Bryn, K. \& Frøholm, L. O. (1988). Restoration of antibody binding to blotted meningococcal outer membrane proteins using various detergents. $J$ Immunol Methods 113, 51-59.

Wedege, E., Bjune, G., Frøholm, L. O., Høiby, E. A. \& Rosenquist, E. (1991). Immunoblotting studies of vaccinee and patient sera from the Norwegian serogroup $B$ meningococcal vaccination trial. NIPH Ann 14, 183-187.

Wetzler, L. M., Blake, M. S. \& Gotschlich, E. C. (1988). Characterization and specificity of antibodies to protein I of Neisseria gonorrboeae produced by injection with various protein I-adjuvant preparations. J Exp Med 168, 1883-1897.
Wiertz, E. J. H. J., Van Gaans-van den Brink, J. A. M., Schreuder, G. M. T. H., Termijtelen, A. A. M., Hoogerhout, P. \& Poolman, J. T. (1991). T cell recognition of Neisseria meningitidis class I outer membrane proteins: identification of $T$ cell epitopes with selected synthetic peptides and determination of HLA restriction elements. J Immunol 147, 2012-2018.

Wiertz, E. J. H. J., Van Gaans-van den Brink, J. A. M., Gausepohl, H., Prochnicka-Chalufour, A., Hoogerhout, P. \& Poolman, J. T. (1992). Identification of ' $\Gamma$ cell epitopes occurting in a meningococcal class 1 outer membrane protein using overlapping peptides assembled with simultaneous multiple peptide synthesis. $J$ Exp Med $176,79-86$.

Wolff, K. \& Stern, A. (1991). The class 3 outer membrane protein (PorB) of Neisseria meningitidis: gene sequence and homology to the gonococcal porin PIA. FEMS Microbiol Lett 83, 179-186.

Zapata, G. A., Vann, W. F., Rubinstein, Y. \& Frasch, C. E. (1992). Identification of variable region differences in Neisseria meningitidis class 3 protein sequences among five group B serotypes. Mol Microbiol 6, 3493-3499.

Received 16 October 1995; revised 5 March 1996; accepted 24 April 1996. 